\title{
The Divine Charioteering Model - A Guide to Moderation
}

Bruce Rishel

Charioteering as a metaphor for correct and balanced thinking has been written about since Homer. The Iliad presents the divine charioteering model as exemplified by Hera and Athena and examines how the fate of mortal charioteers including Antilokhos, Patroklos and Achilles is determined based on their ability to adhere to this model. Authors as diverse as Plato, Proclus, Pindar and Euripides build upon the divine charioteering model as they show examples of charioteers who, in varying degrees, follow this model. This paper will demonstrate that heroes who veer from the model of equilibrium and moderation provided by the gods, violate justice [dikē] with their hubris and incur agony [agōn] from the divinity they antagonize.

Charioteering as a metaphor for correct and balanced thinking has been written about since Homer. The Iliad presents the divine charioteering model as exemplified by Hera and Athena and examines how the fate of mortal charioteers including Antilokhos, Patroklos and Achilles is determined based on their ability to adhere to this model. Authors as diverse as Plato, Proclus, Pindar and Euripides build upon the divine charioteering model as they show examples of charioteers who, in varying degrees, follow this model. This paper will demonstrate that heroes who veer from the model of equilibrium and moderation provided by the gods, violate justice [dikē] with their hubris and incur agony [agōn] from the divinity they antagonize.

Plato's Socrates tells us, "In the case of the gods, the horses and charioteer are noble and good. But in the case of mortals one of the horses is ill-trained and troublesome, thus making the movement of the chariot difficult" [Plato, Phaedrus, 246a]. Nestor, charioteer of Gerenia, "whose counsel was ever truest" [Homer, Iliad, 7. 325] helps his most near and dear [philos] son, Antilokhos, understand how to master what would otherwise prove difficult. In an ainos, that coded form of speech understandable only to the initiated, Nestor says: 
I will tell you a sign [sēma], a very clear one, which will not get lost in your thinking. Standing over there is $\langle\ldots\rangle$ either the tomb [sēma] of some mortal who died a long time ago or was a turning point [nussa] in the times of earlier men. $<\ldots>$ Get as close to it as you can when you drive your chariot horses toward it, and keep leaning toward one side as you stand on the platform of your well-built chariot, leaning to the left as you drive your horses. Your right-side horse you must goad, calling out to it, and give that horse some slack as you hold its reins, while you make your left-side horse get as close as possible so that the hub will seem to be almost grazing the post $<\ldots>$ you must be sound in your thinking and be careful. [Homer, Iliad, 23. 326-44]

These words provide a practical guide to chariot racing, but the ainos is about more than technicalities. Rather, Nestor creates a metaphorical guide to help mortals model divine equilibrium and moderation, and therefore provides a standard that mortals should attempt to imitate in their quest for balance and right thinking.

The divine charioteering model is presented in The Iliad where we see the goddesses Hera and Athena appealing to Zeus for permission to enter the Trojan war on behalf of the Achaeans:

"Into the fiery chariot with her [Athena's] feet she stepped. $<\ldots>$ Hera lashed the horses on, and the gates of the sky bellowed as they flew open. $<\ldots>$ Through these the goddesses drove their obedient steeds, and found the son of Kronos sitting all alone on the topmost ridges of Olympus. There Hera of the white arms stayed her horses, and spoke to Zeus the son of Kronos, lord of all. 'Father Zeus,' said she, 'are you not angry with Arēs for these high doings? < ..> I hope, Father Zeus, that you will not be angry if I hit Arēs hard, and chase him out of the battle'. And Zeus answered, 'Set Athena on to him, for she punishes him more often than anyone else does"'. [Homer, Iliad, 5. 745766]

Through these words, we see in the goddesses clear thinking through their knowledge of when to lash the horses on and when to reign them in; to proceed with haste to Mt. Olympus in the former and to restrain their horses to plead with Zeus in the later. The goddesses are balanced and moderate in their thinking and at equilibrium, mindful of the appropriate time for impulse vs. restraint. This equilibrium in thinking provides a basis for Nestor's ainos.

The efficacy of being at equilibrium in one's thinking is apparent as we see when Athena rides with the mortal Diomedes against the god Arēs:

the goddess mounted the car and placed herself by the side of radiant Diomedes. $<\ldots>$ Pallas Athena took the whip and reins, and drove straight at Arēs. $<\ldots>$ As soon as they were at close quarters he [Arēs] let fly with his bronze spear over the reins and yoke, thinking to take Diomedes' life, but owl-vision Athena caught the spear in her hand and made it fly harmlessly over the chariot. Diomedes of the great war cry then threw, and Pallas Athena drove the spear into the pit of the stomach of brazen Arēs. <..> There Diomedes wounded him, tearing his fair flesh and then 
drawing his spear out again. Arēs roared as loudly as nine or ten thousand men in the thick of a fight. [Homer, Iliad, 5. 837-64]

So effective is the divine charioteering model that we see, through Athena's guidance, Diomedes removing Arēs, a god, from the field of battle. For those who cannot apply right thinking by maintaining equilibrium and moderation, untimely devastation will await.

Beginning with Achilles, we see in him a conflict between action and restraint and the indecision involved in knowing which is best: "And the son of Peleus felt grief [akhos], and the heart within his shaggy chest was divided whether to draw the sharp sword at his thigh $<\ldots>$ while he kills [Agamemnon] the son of Atreus or whether to check his anger [kholos] and restrain his heart [thūmos]". Guided by Athena, Achilles makes the right decision at the right time and equilibrium is maintained: "While he was thus of two minds, and was drawing his mighty sword from its scabbard, Athena, sent by Hera, came down from the sky ... and said, 'I come from the sky, if you will hear me, to bid you stop your anger,... Hold, therefore, and obey.' 'Goddess,' answered swift Achilles, the great runner, 'whatever anger [kholos] a man may have, he must do as you two command him. This will be best, for the gods ever hear the prayers of him who has obeyed them"" [Homer, Iliad, 1. 194- 218]. At this moment, Achilles choses to comport his behavior with the standard provided to him by Athena and remains at equilibrium. As the plot progresses, decisions to obey the gods will faulter as restraint gives way to untimely impulse. Balance must be restored, and the task to do so falls to the god Apollo who is most antagonized by Achilles's actions.

The deadly consequences to Achilles of his imbalance are not shown in The Iliad but we can use Achilles's ritual substitute [therapōn], the charioteer, Patroklos, to examine Achilles's fate. Knowing from his mother, Thetis, the divine plan, Achilles provides battle instructions to Patroklos: "When you have driven the Trojans from the ships, come back again $<\ldots>$ do not fight the Trojans further in my absence" [Iliad R16 86-89]. Patroklos urges on his metaphorical chariot and does as Achilles commands "He drove them [the Trojans] from the ships, and he quenched the blazing fire" [Homer, Iliad, 16. 293-94]. But after this success, Patroklos fails to show proper restraint and violates the divine plan. After 
three successive attempts to reach the high walls of Troy, each time being beaten back, on his fourth attempt Apollo,

shouted to him with a terrifying voice and spoke winged words: 'Draw back, Patroklos, you who are descended from the gods in the sky. It is not your destiny to destroy with your spear the city of the proud Trojans, nor will it be the destiny of Achilles, who is a far better man than you are"'. [Homer, Iliad, 16. 702-809]

This was a divine warning but when Patroklos again rushes into the Trojans, four times, "then, O Patroklos, the end of your life made its appearance to you" [Homer, Iliad, 16. 787].

Patroklos's failure to restrain his impulses and to heed the words of Achilles lead to agony at the hands of Apollo. His failure was one of timing his restraint. Driven by anger Patroklos, gives in to the impulse to attack, he fails to hold back when appropriate and this failure antagonizes the god most like him, Apollo. The consequence of this antagonism is Patroklos's death. Clues to a similar death for Achilles are found in the Epic Cycle of Proclus: "Achilles, while routing the Trojans and rushing into the citadel, is killed by Paris and Apollo" [Proclus, Aithiopis, 7-8]. The untimely urge to rush in when divine command would have the hero restrain himself appear to bring about the early demise of both Patroklos and Achilles at the hands of Apollo who serves as the harbinger of justice [dikē].

In contrast to Achilles and Patroklos, the charioteer Hippolytus shows not an excess of impulse but rather the opposite, an excess of restraint and as with the prior examples, balance is divinely restored. In the case of Hippolytus, he holds back from growing up and in his excessive reverence towards Artemis, goddess of youth, he fails to provide due reverence to Aphrodite goddess of sex and marriage. Aphrodite reminds us, "Powerful among mortals am I and not without reputation $<\ldots>$ I bring to ruin whoever has little regard for my greatness $<\ldots>$ Hippolytus $<\ldots>$ scorns the nuptial bed and takes no notice of marriage" [Euripides, Hippolytus, 1-14]. As a charioteer, Hippolytus fails by metaphorically overly restraining his horses when the timely action given his stage in life would be to goad them on, driving him into manhood.

Despite Hippolytus's skills with horses, there is no defense against divine retribution and its drive towards equilibrium and moderation. As Aphrodite takes her revenge we see "A terrible panic seized the horses at once, but our master [Hippolytus], 
who was quite used to the horses' ways, pulled back as a sailor pulls on an oar, leaning back on the reins with all of his weight; but the horses biting into the forged bits with their jaws wildly bore him on, regardless of their master's guiding hand" [Euripides, Hippolytus, 1216-27]. In his failure to properly master restraint and impulse, Hippolytus fails to follow the divine model of charioteering showing the timely usage of each horse. Balance is restored in myth through Aphrodite's vengeance but it is also restored in ritual where the lessons of Hippolytus are learned through his cult worship in Athens where "unwed girls before they get married will cut off their hair for you [Hippolytus], and throughout the length of time" [Euripides, Hippolytus, 1425-1426]. In this way what was lacking in the myth of Hippolytus is compensated for in ritual of Hippolytus as a cult hero. This ritual provides protection for the polis against the same divine retribution that befell the hero, balance is thus restored.

Returning now to Nestor and his advice to Antilokhos, in Antilokhos we see a youth moderate in his thinking, and (mostly) able to balance impulse and restraint. Menelaos says of him, "Antilokhos $<\ldots>$ you are young and there is none of the Achaeans more fleet of foot or more valiant than you are. See if you cannot spring upon some Trojan and kill him.' $<\ldots>$ Antilokhos, who at once darted out from the front ranks and aimed a spear, $<\ldots>$ but noble Hector marked him... Antilokhos, brave warrior though he was, would not stay to face him, but fled like some savage creature which knows it has done wrong, and flies" [Homer, Iliad, 15. 568-87]. In these actions we see both the impulse to dart to the front and restraint when Antilokhos knows he is no match for Hector. This balance in thinking leads both to his kleos sung by Menelaos who says there are none "more valiant than you are" and for now, to his life which is saved by not confronting Hector.

Antilokhos though is young and not yet a master of charioteering and we see his artlessness when Menelaos rebukes him saying “'Antilokhos, you are driving recklessly; rein in your horses; the road is too narrow here, it will be wider soon, and you can pass me then; if you foul my chariot you may bring both of us to a mischief.' But Antilokhos plied his whip, and drove faster, as though he had not heard him" [Homer, Iliad 23. 418-29]. What Antilokhos lacks in real charioteering skill he makes up for in the charioteering metaphor when, “Antilokhos answered, 'Forgive me; I am much younger, King Menelaos $<\ldots>$ I would rather yield it to you, at once, than fall from your good graces henceforth, 
and do wrong in the eyes of superhuman forces [daimones]"' [Homer, Iliad, 23. 566-87]. After the mistake of his impulsiveness in the chariot race, Antilokhos demonstrates restraint when requesting forgiveness from Menelaos and this request for forgiveness and his proper use of restraint means there is no imbalance in his thinking to divinely correct.

Yet Antilokhos does die, a death shrouded in mystery, Proclus tells us only that "<..> a battle occurs, Antilokhos is killed by Memnon" [Proclus, Aithiopis, 4]. Nestor reveals slightly more: "Our best men all of them fell there-Ajax, Achilles, Patroklos, peer of gods in counsel, and my own dear son, Antilokhos, a man singularly fleet of foot and in fight valiant” [Homer, Odyssey, 3, 109-11]. Yet Pindar reveals the detail:

he died for his father's sake, by awaiting the man-slaying commander of the Ethiopians, Memnon. For the horse kept Nestor's chariot from moving, since it had been wounded by Paris' arrows; and Memnon was aiming his strong spear. The old man of Messene [Nestor], his mind reeling, shouted to his son; the cry he hurled did not fall to the ground; his god-like son stayed on the spot and paid for his father's rescue with his own life, and because he accomplished this tremendous deed he seemed to the younger men to be the greatest man of his time in excellence towards his parents. [Pindar Pythian 6. 28-42].

Like Patroklos, Antilokhos dies as a substitute for another, his death saves the life of Nestor, his father, king of Pylos. All must die but because of Antilokhos's balance and correct thinking in life, his death comes not through divine retribution. He dies rather the death of a hero making a choice to save the life of his father and after death this choice leads to compensation: "When they had passed the waters of Okeanos and the Rock Leukas, they came to the Gates of the Sun and the District [dēmos] of Dreams, whereon they reached the Meadow of Asphodel where dwell the spirits and shadows of them that can labor no more. Here they found the spirit [psūkhē] of Achilles, son of Peleus, with those of Patroklos, Antilokhos and Ajax..." [Homer, Odyssey 24. 11-17]. Thus, Antilokhos is reunited with other heroes of myth in an afterlife where he enjoys the fruits of paradise.

And so, through poetry and prose we are provided a model of correct thinking, a vision of equilibrium and moderation. This model of divine charioteering recognizes that unlike the gods whose "horses and charioteer are noble and good" [Plato, Phaedrus, 246a], mortals face difficulties and struggle in their choices knowing when to use impulse and when to restrain. The charioteers, like the kubernētēs or steersmen in the Homeric Hymn to Dionysus, are called to follow a tack of moderation. If the charioteer is capable then he, like the kubernētēs, "the one who had a heart [thūmos] that is moderate [sōphrōn]" [Homeric 
Hymn to Dionysus, 48-50], will become, as Dionysus tells us, "the most blessed [olbios] of all men" and will have "achieved beauty and pleasure" that brings joy to Dionysus's heart. [Homeric Hymn to Dionysus, 54-55].

Bruce Rishel

Harvard University

\section{Works Cited}

Nagy, G., 2019. Sourcebook of Ancient Greek Texts in English Translation. [Online] Available at: http://nrs.harvard.edu/urn-3:hul.ebook:CHS_NagyG_ed.Sourcebook_H24H.2013-[Accessed 8 December 2019].

Pindar, n.d. Pythian 6. [Online] Available at: http://www.perseus.tufts.edu/hopper/text?doc=urn:cts: greekLit:tlg0033.tlg002.perseus-eng1:6 [Accessed 8 December 2019]. Plato, n.d. Plato's Phaedrus. [Online]

Available at: http://caae.phil.cmu.edu/Cavalier/80250/Plato/Phaedrus/Phaedrus.html [Accessed 8 December 2019]. 